\section{УДК 351.851.352:373.5.016:37.091. 214-053.5-056.24}

\section{Кухарчук Петро Михайлович,}

кандидат наук з державного управління, дочент, професор кафедри суспільно-гуманітарних дисииплін, Комунальний заклад “Житомирський обласний інститут післядипломної педагогічної освіти" Житомирської обласної ради, 10014, м. Житомир, вул. Михайлівська, 15, к. 14, тел.: +38 (067) 41280 55, e-mail: kpmkpma@ gmail.com

ORCID: 0000-0002-2051-3298

\section{Кухарчук Петр Михайлович,}

кандидат наук по государственному управлению, доцент, профессор кафедры общественно-гуманитарных дисциплин, Коммунальное учреждение “Житомирский областной институт последипломного педагогического образования” Житомирского областного совета, 10014, г. Житомир, ул. Михайловская, 15, к. 14, тел.: +38 (067) 41280 55, e-mail: kpmkpma@gmail.com

ORCID: 0000-0002-2051-3298

\section{Kukharchuk Petro Mykhailozych,}

PhD in Public Administration, Associate Professor, Professor of the Department of Social and Humanitarian Disciplines, Municipal Institution "Zhytomyr Regional InService Teacher Training Institute" of Zhytomyr Regional Council, 10014, Zhytomyr, Str. Mikhaylivska, 15, room 14, tel.: +38 (067) 41280 55, e-mail:kpmkpma@gmail.com

ORCID: 0000-0002-2051-3298

\section{Коврігіна Лілія Михайлівна,}

кандидат філологічних наук, завідувач кафедри суспільно-гуманітарних дисциплін, Комунальний заклад “Житомирський обласний інститут післядипломної педагогічної освіти” Житомирської обласної ради, 10014, м. Житомир, вул. Михайлівська, 15, к. 14, тел.: +38 (097) 24773 33, e-mail: kovriginalilija@i.иа

\section{Ковригина Лилия Михайловна,}

ORCID: 0000-0002-6008-7211

кандидат филологческих наук, заведующая кафедрой общественно-гуманитарных дисииплин, Коммунальное учреждение “Житомирский областной институт последипломного педагогического образования" Житомирского областного совета, 10014, г. Житомир, ул. Михайловская, 15, к. 14, тел.: +38 (097) 24773 33, е-таil: kovriginalilija@i.ua

ORCID: 0000-0002-6008-7211 


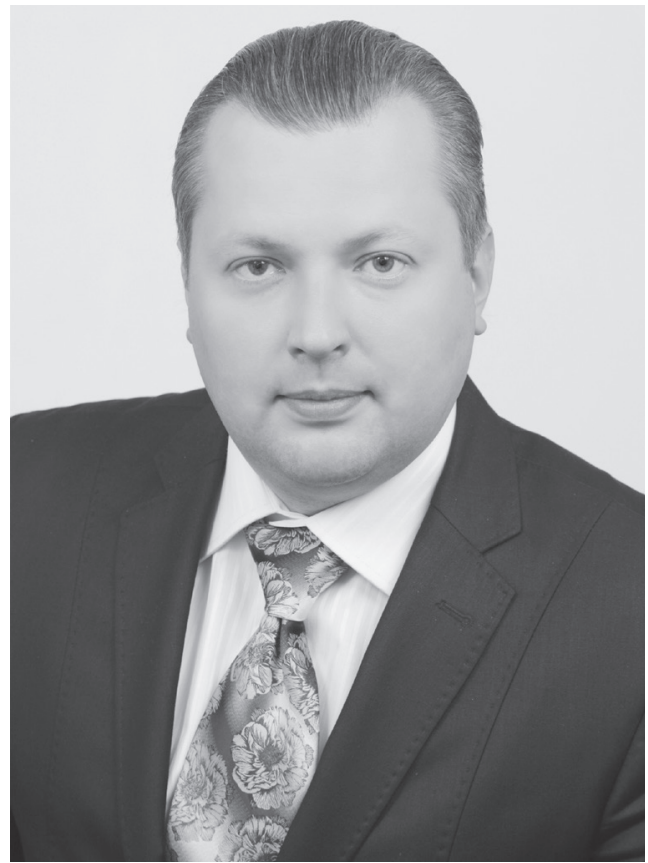

Kovrigina Liliya Mikhailovna,

candidate of philological sciences, head of the department of social and humanitarian disciplines Communal institution "Zhytomyr Regional Institute of Postgraduate Pedagogical Education" Zhytomyr Regional Council, 10014, Zhytomyr, Str. Mikhailivska, 15, room. 14, tel.: +38 (097) 24773 33, e-mail: kovriginalilija@i.ua

$$
\text { ORCID: 0000-0002-6008-7211 }
$$

\section{Калінін Вадим Олександрович,}

кандидат педагогічних наук, доцент, завідувач лабораторії упровадження освітніх інновацій, Комунальний заклад “Житомирський обласний інститут післядипломної педагогічної освіти” Житомирської обласної ради, 10014, м. Житомир, вул. Михайлівська, 15, к. 20, тел.: +38 (067) 41011 61, e-mail: vadimkalinin76@ gmail.com

ORCID: 0000-0001-8254-5482

\section{Калинин Вадим Александрович,}

кандидат педагогиеских наук, доцент, заведующий лабораторией внедрения образовательных инноващий, Коммунальное учреждение “Житомирский областной институт последипломного педагогического образования” Житомирского областного совета, 10014, г. Житомир, ул. Михайловская, 15, к. 20, тел.: +38 (067) 41011 61, е-таil: vadimkalinin76@gmail.com

ORCID: 0000-0001-8254-5482

\section{Kalinin Vadim Oleksandrovych,}

PhD in Philological science (theory and methods of professional education), Associate Professor, Head of the Laboratory of Educational Innovations, Municipal Institution "Zhytomyr Regional In-Service Teacher Training Institute" of Zhytomyr Regional Council, 10014, Zhytomyr, Str. Mikhaylivska, 15, room 20, tel.: +38 (067) 41011 61, e-mail:vadimkalinin76@gmail.com

ORCID: 0000-0001-8254-5482

DOI: 10.32689/2617-2224-2018-15-5-123-139

\section{ОСОБЛИВОСТІ ЗАПРОВАДЖЕННЯ ІНКЛЮЗИВНОї ОСВІТИ В УКРАЇНІ}

Анотація. Зроблено спробу аналізу запровадження інклюзивної освіти в Україні. Висвітлено реформування системи освіти, забезпечення рівного доступу до якісної освіти всіх дітей, включаючи дітей з особливими освітніми потребами. Розкрито особливості інклюзивної форми навчання в сучасній українській школі, що передбачає дитині, яка потребує корекції психофізичного розвитку, право відвідувати загальноосвітній заклад і го- 
товності педагогічних працівників до психолого-педагогічного супроводу дитини.

Схарактеризовано імплементацію Закону України “Про освіту” щодо реформування системи освіти, забезпечення рівного доступу до якісної освіти всіх дітей, включаючи дітей з особливими освітніми потребами. Розкрито актуальне значення інклюзивної форми навчання у сучасній українській школі, яку передбачено для дитини, що потребує корекції психофізичного розвитку, право відвідувати загальноосвітній заклад і готовність педагогічних працівників до психолого-педагогічного супроводу дитини.

Висвітлено зміщення акцентів соціальної політики держави стосовно людей з інвалідністю у бік формування суспільної свідомості щодо сприйняття їх як рівних членів суспільства та необхідності створення для цих громадян умов для повноцінного життя, в тому числі здобуття освіти. Законодавчо визнано право дітей з особливими освітніми потребами на навчання в освітніх закладах за місцем проживання.

Розкрито питання включення дітей з особливими освітніми потребами в дитячий колектив якомога раніше, починаючи з дошкільного віку.

Схарактеризовано використання нетрадиційних форм і методів роботи, що на практиці довели свою ефективність та результативність в освіті дорослих. Готуючи майбутніх педагогічних працівників, інститути післядипломної педагогічної освіти та інші установи, які займаються підвищенням кваліфікаціï, мають включати в освітні програми інклюзивну тематику та формувати у педагогів психологічну та професійну готовність до роботи з дітьми з особливими освітніми потребами. Необхідно надати їм знання зі спеціальної та соціальної педагогіки, забезпечити інструментарієм та моделями альтернативного навчання, використовуючи воркшоп (інтенсивний навчальний захід, під час якого дорослі навчаються через власну активність).

Ключові слова: інклюзивна освіта, реформування системи освіти, педагогічні працівники, психолого-педагогічний супровід дитини, корекція психофізичного розвитку, навчання дорослих.

\section{ОСОБЕННОСТИ ВНЕДРЕНИЯ ИНКЛЮЗИВНОГО ОБРАЗОВАНИЯ В УКРАИНЕ}

Аннотация. Предпринята попытка анализа внедрения инклюзивного образования в Украине. Освещены вопросы реформирования системы образования, обеспечения равного доступа к качественному образованию всех детей, включая детей с особыми образовательными потребностями. Раскрыты особенности инклюзивной формы обучения в современной украинской школе, предусматривающий ребенку, который нуждается в коррекции психофизического развития, право посещать общеобразовательные заведения и готовности педагогов к психолого-педагогического сопровождению ребенка.

Охарактеризована имплементация Закона Украины "Об образовании" по реформированию системы образования, обеспечение равного доступа к 
качественному образованию всех детей, включая детей с особыми образовательными потребностями. Раскрыто актуальное значение инклюзивной формы обучения в современной украинской школе, предусматривающей для ребенка, который нуждается в коррекции психофизического развития, право посещать общеобразовательное заведение и готовность педагогов к психолого-педагогическому сопровождению ребенка.

Освещены смещение акцентов социальной политики государства в отношении людей с инвалидностью в сторону формирования общественного сознания относительно восприятия их как равных членов общества и необходимость создания для этих граждан условий для полноценной жизни, в том числе получения образования. Законодательно признано право детей с особыми образовательными потребностями на обучение в образовательных учреждениях по месту жительства.

Раскрыты вопросы включения детей с особыми образовательными потребностями в детский коллектив как можно раныше, начиная с дошкольного возраста.

Охарактеризовано использование нетрадиционных форм и методов работы, которые на практике доказали свою эффективность и результативность в образовании взрослых. Готовя будущих педагогов, институты последипломного педагогического образования и другие учреждения, которые занимаются повышением квалификации, должны включать в образовательные программы инклюзивную тематику и формировать у педагогов психологическую и профессиональную готовность к работе с детьми с особыми образовательными потребностями. Необходимо предоставить им знания по специальной и социальной педагогике, обеспечить инструментарием и моделями альтернативного обучения, используя воркшоп (интенсивное учебное мероприятие, во время которого взрослые учатся посредством собственной активности)..

Ключевые слова: саморегулирование, технический надзор, технический аудит, государственное регулирование, дерегуляция, децентрализация, инжиниринг, строительная отрасль.

\title{
CHARACTERISTIC FEATURES OF INTRODUCTION OF INCLUSIVE EDUCATION IN UKRAINE
}

\begin{abstract}
In this article an attempt to analyze the introduction of inclusive education in Ukraine is made. The reform of the education system, providing equal access to quality education for all children, including children with special educational needs, is highlighted. The peculiarities of the inclusive form of education in modern Ukrainian school are revealed, which include the right of a child who needs correction of psychophysical development, to attend general educational institutions and readiness of pedagogical staff for psychological and pedagogical support of the child.

The implementation of the Law of Ukraine "On Education" on reforming the education system, ensuring equal access to quality education for all children, including children with special educational needs, is characterized. The actual sig-
\end{abstract}


nificance of the inclusive form of education in the modern Ukrainian school is revealed, which implies the right of a child who needs correction of psychophysical development to attend general educational institutions and readiness of pedagogical staff for psychological and pedagogical support of the child.

A shift of emphasis of the state's social policy concerning disabled people towards the formation of public consciousness regarding their perception as equal members of society and the need to create conditions for those citizens to live life to the full, including education, is highlighted. Legally recognized the right of children with special educational needs to study in educational institutions at their place of residence.

The issue of the inclusion of children with special educational needs in the children's collective as soon as possible, starting from preschool age, is described.

Within the education of adults the use of non-traditional forms and methods of work is described, which proved its efficiency and effectiveness. While preparing future pedagogical staff, institutes of postgraduate pedagogical education and other institutions involved in further training should include inclusive subjects in educational programs and educate psychologists and professionals to work with children with special educational needs. It is necessary to provide them with knowledge of special and social pedagogy, as well as tools and models of alternative learning with the use of workshop (an intensive educational activity in which adults learn through their own activities).

Keywords: inclusive education, reformation of the educational system, pedagogical workers, psychological and pedagogical support of the child, correction of psychophysical development, adult education..

Постановка проблеми. Права дитини рівні серед усіх членів суспільства “без будь-якої б то не було різниці за такими ознаками як раса, колір шкіри, стать, релігія, політичні або інші переконання, національне та соціальне походження, майновий стан, народження або інші обставини" [1]. Статтею 20 Закону України "Про освіту" визначено механізми реалізації інклюзивної освіти в Україні, де закладами освіти за потреби утворюються інклюзивні та/або спеціальні групи і класи для навчання осіб з особливими освітніми потребами. У разі звернення особи з особливими освітніми потребами або їі батьків така група або клас утворюється в обов'язковому порядку. Заклади освіти зі спеціальними та інклюзивними групами і класами створюють умови для навчання осіб з особливими освітніми потребами відповідно до індивідуальної програми розвитку та з урахуванням їхніх індивідуальних потреб і можливостей. Особи з порушеннями фізичного, психічного, інтелектуального розвитку і сенсорними порушеннями забезпечуються у закладах освіти допоміжними засобами для навчання [2].

На сучасному етапі в системі освіти України спостерігаються прихова- 
ні негласні форми дискримінації за вказаними ознаками, які впродовж десятиліть настільки стали суспільною нормою, що вийшли за межі усвідомлення членами суспільства. Насамперед це стосується дітей 3 особливими освітніми потребами, які тривалий час були ізольованими від суспільства, навчаючись в спеціальних інтернатних закладах або за індивідуальною формою навчання.

Імплементація ст. 20 Закону України "Про освіту" передбачає реформування системи освіти, забезпечення рівного доступу до якісної освіти всіх дітей, включаючи дітей 3 особливими освітніми потребами. Актуального значення набуває інклюзивна форма навчання в сучасній українській школі, що передбачає дитині, яка потребує корекції психофізичного розвитку, право відвідувати загальноосвітній заклад i готовності педагогічних працівників до психолого-педагогічного супроводу дитини.

Аналіз останніх досліджень i публікацій. Проблеми інклюзивної освіти в останні роки перебували в центрі робіт багатьох вітчизняних та зарубіжних науковців: A. Dyson, A. Millward, C. Clarke, D. Mitchell, S. Robson,T. Loreman, Л. Даниленко, А. Колупаєва, Н. Купустин, Ю. Найда, М. Сварник, Н. Софій, П. Троханіс, С. Юсфін, Е. Ямбург, Е. Андрєєва, В. Бондаря, Т. Ілляшенко, А. Колупаєвої, Н. Сабат, Є. Ярської-Смирнової, О. Акімової, Т. Сак, Л. Савчук, Л. Прядко та ін.

Формуванню готовності до роботи в інклюзивному освітньому просторі присвячені праці таких науковців, як I. Садова, В. Сулим, І. Демченко,
Е. Данілавічуте. Проте, на нашу думку, є пошук досліджень інклюзії, що стосуються проблем дітей з особливими освітніми потребами в сучасній системі освіти, підготовки вчителів до цілісного психолого-педагогічного супроводу дитини.

Мета статті - висвітлення й обгрунтування проблем забезпечення права на здобуття якісної освіти дітей $з$ особливими освітніми потребами і перспектив їх вирішення в сучасній українській школі.

Виклад основного матеріалу. Зміна освітньої парадигми на гуманістичну модель - "освіта для всіх, школа для всіх", в основу якої покладено концепцію цілісного підходу, що відкриває шлях до реалізації прав і можливостей кожної людини i, перш за все, передбачається рівний доступ дітей з особливими потребами до здобуття якісної освіти.

Зміщення акцентів соціальної політики держави стосовно інвалідів у бік формування суспільної свідомості щодо сприйняття їх як рівних членів суспільства та необхідності створення для цих громадян умов для повноцінного життя, в тому числі здобуття освіти. Законодавчо визнано право дітей з особливими освітніми потребами на навчання в освітніх закладах за місцем проживання.

У вересні 2017 р. Верховна Рaда України прийняла зміни № 6437 "Про внесення змін до Закону України "Про освіту” щодо особливостей доступу осіб з особливими освітніми потребами до освітніх послуг”.

Тепер діти з особливими освітніми потребами поряд з іншими формами навчання (спеціальною, індивідуальною) можуть навчатися за інклюзив- 
ною формою поряд зі здоровими однолітками, не відриваючись від свого природнього середовища. Право вибору освітнього закладу для своєї дитини надано батькам. До інклюзивного класу дитина з особливими освітніми потребами зараховується на підставі заяви батьків та висновку спеціалістів інклюзивно-ресурсного центру. Школа має забезпечити створення належних умов для повноцінної реалізації кожної дитини своїх потенційних можливостей, включаючи дітей $з$ особливими освітніми потребами.

У центрі “інклюзивної” школи $е$ дитина незалежно від стану здоров’я, фізичних чи розумових здібностей, соціального статусу сім'ї тощо. Система освіти адаптується до потреб будь-якої дитини. Адаптація відбувається на рівні фізичного середовища, освітніх програм, методів викладання, здійснення індивідуального підходу до кожної дитини, застосування особистісно орієнтованих технологій, диференційованого викладання та ін. Дитина з особливими освітніми потребами навчається за умови психолого-педагогічного супроводу, який здійснює міждисциплінарна команда спеціалістів (учителів, психологів, соціальних та корекційних педагогів, батьків та ін.).

Держава сприяє підтримці дітей 3 особливими освітніми потребами, надаючи Субвенцію 3 державного бюджету місцевим бюджетам на надання державної підтримки особам з особливими освітніми потребами (Постанова Кабінету Міністрів України від 14 лютого 2017 р. № 88) [3]. Порядок та умови визначають механізм надання субвенції з державного бюджету місцевим бюджетам на надання державної підтримки особам з особливими освітніми потребами (далі - субвенція). Головний розпорядник субвенції - МОН. Розпорядниками субвенції за місцевими бюджетами є структурні підрозділи 3 питань освіти і науки місцевих органів виконавчої влади та органів місцевого самоврядування, які визначаються рішенням відповідної місцевої ради про такий бюджет згідно із законодавством.

Субвенція спрямовується на надання державної підтримки особам 3 особливими освітніми потребами, які навчаються у спеціальних та інклюзивних класах закладів загальної середньої освіти (крім шкіл-інтернатів, спеціальних шкіл (шкіл-інтернатів), санаторних шкіл (шкіл-інтернатів) та навчально-реабілітаційних центрів), а саме дітям сліпим та зі зниженим зором, глухим та зі зниженим слухом, 3 тяжкими порушеннями мовлення, із затримкою психічного розвитку, з порушеннями опорно-рухового апарату, з порушенням інтелектуального розвитку, зі складними порушеннями розвитку (в тому числі з розладами аутичного спектра).

За рахунок субвенції здійснюється оплата таких видатків:

- проведення (надання) додаткових корекційно-розвиткових занять (послуг), що визначені індивідуальною програмою розвитку для учнів інклюзивних класів та робочим навчальним планом (індивідуальним навчальним планом учня) для учнів спеціальних класів;

- придбання спеціальних засобів корекції психофізичного розвитку, які дають змогу дитині опанувати 
навчальну програму. На придбання зазначених засобів використовується не більш як 35 \% загального обсягу видатків на кожну дитину відповідного закладу загальної середньої освіти, яка потребує державної підтримки. За наявності у закладі кількох дітей 3 особливими освітніми потребами з однаковими нозологіями в разі потреби можлива закупівля спеціальних засобів корекції психофізичного розвитку для спільного користування. Типовий перелік спеціальних засобів корекції психофізичного розвитку для дітей 3 особливими освітніми потребами затверджується наказом МОН та розміщується на офіційному веб-сайті Міністерства.

У 2018 році субвенція в обсязі 100000 тис. грн спрямовується на оснащення кабінетів інклюзивно-ресурсних центрів для надання психолого-педагогічної допомоги дітям з особливими освітніми потребами (придбання методичного, навчального та програмного забезпечення, предметів, матеріалів і обладнання, у тому числі довгострокового користування) відповідно до вимог, затверджених $\mathrm{MOH}$ ) [3].

Наказом МОН України від 01.02.2018 р. № 90 виділено ставку асистента вчителя інклюзивного класу. У школах, в яких навчання дітей 3 особливими освітніми потребами організоване в спеціальних класах, для здійснення освітнього процесу та проведення корекційно-розвиткових занять, що визначені робочим навчальним планом, вводяться посади вчителів-дефектологів (вчителялогопеда, сурдопедагога, тифлопедагога, олігофренопедагога), інших спеціалістів з відповідною підготовкою.

У школах, в яких навчання дітей 3 особливими освітніми потребами організоване в інклюзивних класах, для проведення корекційно-розвиткових занять, що визначені індивідуальною програмою розвитку, можуть вводитись посади вчителів-дефектологів (вчителя-логопеда, сурдопедагога, тифлопедагога, олігофренопедагога) за наявності навантаження не менше ніж 9 навчальних годин на тиждень, виходячи 3 норми на ставку 18 навчальних годин на тиждень) [4].

Асистент вчителя вводиться у школах, де запроваджене інклюзивне навчання, для роботи з учнями 3 особливими освітніми потребами 3 розрахунку 1 ставка на клас, у якому навчаються такі діти. Таким чином запроваджуються механізми повноцінного забезпечення прав дітей з особливими освітніми потребами на здобуття якісної освіти за місцем проживання.

Перед тим, як констатувати низку проблем, що стосуються інклюзивної освіти, які призводять до того, що інклюзивні процеси в Україні багато хто сприймає негативно, навіть вороже. Це стосується як дитячого колективу, в якому перебуває школяр з особливими освітніми потребами, батьків таких учнів, а також батьків здорових дітей та педагогів і громадськості загалом.

Створення сприятливого клімату в шкільному середовищі є необхідною умовою успіху включення дитини з особливими освітніми потребами в середовище здорових однолітків, що означає прийняття та розуміння такої дитини, визнання 
iii рівноправним членом дитячого колективу. Тільки за таких умов дитина $з$ особливими освітніми потребами почуватиметься комфортно i зможе навчатися. На жаль, непоодинокими є ситуації в закладах освіти, де дитину з порушеннями розвитку однокласники сприймають вороже, насміхаються, глузують, не бажаючи навчатися з нею. Без сумніву, це проблема індивідуальна, яка стосується рівня вихованості учнів, їхньої толерантності, поваги до інших людей (не лише до людей з порушеннями, а також до людей похилого віку, батьків, тварин тощо). У сучасній дійсності, коли нагальною потребою системи освіти постає проблема формування у школярів загальнокультурної компетентності, що передбачає як засвоєння культурного історичного досвіду українського народу, так i формування моральних якостей (доброти, милосердя, співчуття, толерантності тощо), у зв'язку з втратою таких якостей сьогоднішнім молодим поколінням, які переважно живуть у віртуальному світі ілюзій, сформованих комп'ютерними іграми, Інтернетом, телебаченням, навчання поряд з дітьми, які потребують захисту і допомоги, створить реальне середовище для формування таких якостей, що зрештою буде корисним як для дітей з особливими освітніми потребами, так і для їх здорових ровесників.

У закордонній і вітчизняній науці в останні роки постає питання включення дітей з особливими освітніми потребами в дитячий колектив якомога раніше, починаючи 3 дошкільного віку. Перебуваючи всі разом у дитячому садочку, діти 3-6 років ще не зовсім розуміють різниці між собою, але вони звикають один до одного, вчаться жити поряд, знаходячи способи взаємодії та взаєморозуміння. 3 раннього віку вони починають розуміти, з якими труднощами стикаються люди, які мають проблеми розвитку, стають чутливими до потреб інших, толерантніше сприймають людські відмінності, вчаться підтримувати один одного, позитивно взаємодіяти. Приходячи в школу, вони вже мають певні соціальні навички, сформовані в розмаїтому дитячому колективі, тому сприйняття дітей з особливими освітніми потребами не викликатиме будь-яких проблем. У школі цей процес продовжуватиметься і в доросле життя як діти з особливими освітніми потребами, так і їхні ровесники з типовим рівнем розвитку йтимуть зі сформованими в різноманітному соціумі життєвими компетентностями.

Серед наукових досліджень основними положеннями, що визначають суть професійної компетентності вчителя у вітчизняній науці $є$ :

- формування компетентності в основі - спеціалізація (поглиблене вивчення конкретної сфери діяльності);

- виявлення компетентності в діяльності. Ефективність діяльності, рівень успішності вирішення професійних завдань $є$ критерієм компетентності;

- компетентною є людина, яка знає, як потрібно успішно діяти в тій чи іншій ситуації, що виникає в процесі професійної діяльності;

- швидкі темпи розвитку наукової інформації вимагають, щоб професійні знання були з високим рів- 
нем узагальнення, універсальності, відображати системні зв'язки між різними об’єктами дійсності;

- структура компетентності є синтезом та органічною єдністю трьох видів професійних знань, від яких залежить ефективність і рівень діяльності: теоретичні (концептуальні), прикладні й конкретно-професійні;

- компететнтність як інформаційний потенціал людини має особистісно неповторний характер, що зумовлений індивідуальними теоретичними й образними моделями результатів діяльності, орієнтованими основами. Отже, формування професійної компетентності представлене не як оволодіння знаннями засобів досягнення мети, а як оволодіння засобами проектування та здійснення діяльності особистісно неповторним способом;

- компетентність є відносним поняттям: людина може бути компетентністна не загалом, а в конкретній сфері. Рівень компетентності фахівця залежить від різноманітності та складності завдань, які може вирішити [5. с. 84-124].

Необхідно зазначити, що процес формування таких компетентностей відбувається цілісно як у шкільному, так і в родинному середовищах та в колі друзів тощо. Говорячи про шкільний соціум, тут важливо наголосити на тому, що формування позитивного клімату для учнів 3 особливими освітніми потребами залежить не лише від сприйняття їх дитячим колективом, а й від педагогів. На даний час думки вітчизняних педагогів стосовно інклюзивної освіти мають широкий діапазон: одні розуміють їі переваги та впевнені в необхідності інклюзивного навчання, бачать у цьому підтримку для вчителя та позитивні зміни в системі шкільної освіти, інші, навпаки, скептично ставляться навіть до самої ідеї інклюзивної освіти, яка викликає в них відвертий жах від однієї думки про навантаження, яке ляже на їхні плечі. Елементарна інформаційна необізнаність, недостатнє володіння педагогічними технологіями та основами психології і корекційної педагогіки, неготовність працювати в команді з іншими спеціалістами, емоційне неприйняття дітей з різними типами вад та ментальна неготовність включати таких дітей у звичну шкільну діяльність є основними аргументами позиції педагогів. Якщо вони ще не проти працювати з дітьми, які мають сенсорні порушення, то дітей $з$ розладами аутичного спектра, поведінки, розумовими вадами вчителі не готові сприймати, оскільки, на їхню думку, зважаючи на важкість порушення, дитина не зможе отримати повної користі від інклюзивного навчання, що інклюзія спричинить додаткове навантаження на вчителів звичайної школи й на учнів, і що внаслідок надто серйозних розладів поведінки дитина може заподіяти шкоду навколишнім.

Згадаймо В. Сухомлинського: “Учитель починається 3 любові до дитини” [6]. Якими критеріями вимірювати любов до дитини у вступників до педагогічних закладів чи у вчителя? Сучасний випускник педагогічного університету чи коледжу, прийшовши в школу, стає спочатку в оборону свого предмета, вважаючи це головним своїм завданням, тому часто доводиться спостерігати, 
як учитель у школі сприймається спочатку як “мовник”, “математик”, “географ” (бо свій фах він любить), а вже потім як педагог-вихователь. Ми маємо педагогів у школі, які бачать лише свій предмет, програму, а не дитину, для яких іменники, прикметники, дискримінанти, функцї та будова квітки стають важливішими за почуття дитини, ii внутрішній світ, інтереси, прагнення та сподівання. Чи готовий такий учитель перебудуватись з оборонця свого предмета на вихователя, якому важливою є перш за все дитина?

На нашу думку, інклюзивною формою навчання може займатися той, хто прийшов у школу за покликанням. Як відомо, сьогодні в педагогічні заклади вищої освіти відбирають вступників, оцінюючи їхні знання з предметів, а не любов до дитини, людяність, альтруїзм, терпимість, готовність розуміти та сприймати іншого, а саме ці риси важливі для педагогічної діяльності в інклюзивному просторі; суспільство начебто забуло про те, що педагогічна діяльність - це насамперед покликання, творчість, а не ремесло.

Науковець Я. Швень щодо освіти дорослих передбачає використання нетрадиційних форм і методів роботи, що на практиці довели свою ефективність та результативність. Готуючи майбутніх педагогічних працівників, інститути післядипломної педагогічної освіти та інші установи, які займаються підвищенням кваліфікації, мають включати в освітні програми інклюзивну тематику та формувати в педагогів психологічну та професійну готовність до роботи 3 дітьми з особливими освітніми по- требами. Необхідно надати їм знання спеціальної та соціальної педагогіки, забезпечити інструментарієм та моделями альтернативного навчання, використовуючи - воркшоп (це інтенсивний навчальний захід, під час якого дорослі навчаються через власну активність). Узагальнюючи вчення німецького психолога і психотерапевта Клауса Фогеля, Я. Швень пропонує низку його практичних ідей, прийомів і технік динамічного навчання дорослих:

- мозок як комплексна адаптивна система: організовуючи освітній процес, треба враховувати різноманітні аспекти психічної діяльності дорослого: почуття, відчуття, емоціі, увага, сприйняття тощо;

- психіка як соціальний феномен: самоідентичність залежить від того, чи відчуваємо ми свою належність до інших і чи є змога взаємодіяти 3 ними:

- фізіологічні чинники: фізіологічні особливості (стрес, їжа тощо) впливають на освітній процес. Слід враховувати найоптимальніший час для навчання - його визначають за індивідуальними й природними біологічними ритмами й циклами (запланувати перерву, міні-перерву; беручи до уваги ольфакторні чинники сприйняття - шум, запахи, освітлення та ін.);

• “у пошуках сенсу”: під час проведення воркшопу потрібно гарантувати стабільність і довірливість. Освітній процес повинен містити з одного боку, певну провокацію, а з іншого можливість “інсайтів”. Ось чому важливо, щоб навчання дорослих було цікаве й давало змогу управляти власним освітнім процесом, вироб- 
ляти індивідуальну траєкторію особистісно-професійного розвитку;

- потреба пошуку відомчої та нової інформащї: дорослі намагаються завжди віднайти вже відомі паттерни, інтерпретують нові знання через власний досвід, осмислюють його. Важливо організувати освітній процес так, щоб кожний слухач міг зробити власні висновки;

- иінність почуттів у навчанні: слід ретельно стежити за емоційним кліматом у групі, що створює можливість відкритої комунікації. Така взаємодія дає змогу всім слухачам відкрито говорити про те, що відбувається з ними, про їхні почуття, емоції. У групі важливо створити атмосферу підтримки, взаємоповаги й визнання;

- диференціація й узагальнення інформаціи: продуктивний освітній процес має бути організований так, щоб формувати навички частинками й досягти розуміння нової інформації поступово. 3 іншого боку, частини й ціле взаємозалежні, тому слухачі повинні побачити цілісний процес того, що вони опановують;

- особливості уваги дорослого: окрім того, що потрібно контролювати рівень шуму, освітлення й температуру в приміщенні, необхідно свідомо використовувати символи, що позитивно впливають на периферичне сприйняття: плакати, малюнки, презентації (візуальне сприйняття інформації), музичний супровід (аудіальне сприйняття інформації), психологічні вправи на взаємодію (тактильне сприйняття інформації);

- свідоме й несвідоме навчання: під час активного оцінювання учасники можуть осмислювати досвід і зрозуміти, як і чому саме вони навчилися;

- різні можливості запам'ятовування інформачій: важлива й неважлива інформація запам'ятовується по-різному. Факти й навички, що опанували окремо, треба частіше повторювати й практикувати. Що менше інформація та навички пов'язані з актуальним професійним досвідом і знаннями, то більших зусиль потребуе їх утримання в пам'яті. Процес навчання стане ефективніший, якщо в ньому задіяна "особистісна” пам'ять - особистий досвід учасника;

- якість розуміння інформацї̈ залежить від того, наскільки їі можна відчути: під час навчання треба враховувати процеси переживання: використовувати різноманітні дії (демонстрації, проекти, дослідження, візуальну уяву, метафори, рольові ігри, діалог, полілог, ведення щоденника, танці, пантоміму тощо);

- навчання протягом життя: для слухачів потрібно віднайти стимули навчання. Вирішальне значення має нагода отримувати задоволення й відчувати себе продуктивними членами групи. Тому дорослим важливо, що їхні духовні потреби бралися до уваги;

- зачікавленість й азарт в освіmi дорослих: у навчальній групі слід створити атмосферу, що сприяє “поміркованій” увазі, в якій мало страху та багато почуттів. Ситуативний стрес - неминучий: будь-яке навчання активізує особистісні зміни, що пов'язані з невизначеністю. Слухачі зможуть витримувати таку невизначеність і виробити до неї толерантне ставлення; 
- унікальність мозку: освітній процес повинен бути різноманітним, щоб усі слухачі групи могли задіяти свої візуальні, аудіальні, емоційні, вербальні й невербальні здібності. Тому постійно треба давати слухачам можливість вибору, щоб стимулювати індивідуальну зацікавленість. Слід обирати навчальні стратегії та прийоми, щоб вони допомагали кожному слухачеві групи оптимально задіяти мозок;

- теорія семи інтелектів: Говард Гарднер запропонував теорію “семи інтелектів”, що відкриває можливості андрагогу створити цікавий та ефективний навчальний процес. Адже інтелект - це здатність успішно реагувати на нові ситуації й навчатися на власному досвіді;

- психологічні особливості освіти дорослих: дорослі вчать тільки те, що вони готові вчити; дорослі краще вчаться тому, що вони реально роблять; дорослі вчаться на своїх помилках; дорослим легше вчити те, що їм знайомо [7, с. 12-16].

3 метою забезпечення права дітей 3 особливими освітніми потребами віком від 2 до 18 років на здобуття дошкільної та загальної середньої освіти, в тому числі у закладах професійної (професійно-технічної) освіти та інших закладах освіти, які забезпечують здобуття загальної середньої освіти, шляхом проведення комплексної психолого-педагогічної оцінки розвитку дитини (далі - комплексна оцінка), надання психолого-педагогічних, корекційно-розвиткових послуг та забезпечення їх системного кваліфікованого супроводу є утворення установ "Інклюзивно-ресурсних центрів”. Вони провадять діяльність з урахуванням таких принципів, як повага та сприйняття індивідуальних особливостей дітей, дотримання найкращих інтересів дитини, недопущення дискримінації та порушення прав дитини, конфіденційність, доступність освітніх послуг з раннього віку, міжвідомча співпраця.

Інклюзивно-ресурсні центри утворюються з розрахунку один інклюзивно-ресурсний центр не більш як на 7 тис. дітей, які проживають на території об'єднаної територіальної громади (району), та не більш як на 12 тис. дітей, які проживають у місті (районі міста) [8].

Основними вимогами до професійної компетентності вчителя в умовах упровадження інклюзивної освіти, на думку науковців Т. Гура, Л. Чернікової, забезпечення яких має здійснюватися саме в системі післядипломної освіти педагогічної освіти, є:

- цінісно-мотиваційна складова професійної компетентності вчителя в умовах упровадження інклюзивної освіти, характеризується насамперед прийняттям ним цінностей філософії інклюзивної освіти, гуманістичною спрямованістю, позитивною мотивацією професійного й особистісного саморозвитку. Вона є системокоригувальною, визначає функціональну єдність усіх інших складових;

- когнітивна складова містить систему теоретичних і методичних знань у сфері інклюзивної освіти, а саме: сутності і інклюзивної освіти (принципів, змісту, форм, методів тощо), її відмінностей від інших освітніх форм; особливостей психофізичного розвитку дітей, психологічних 
закономірностей та особливостей вікового й особистісного розвитку дітей $з$ особливостями психофізичного розвитку; методів психологічного та дидактичного проектування навчального процесу для спільного навчання дітей тощо;

- конструктивна складова професійної компетентності вчителя в умовах упровадження інклюзивної освіти складається із системи особливих аналітико-прогностичних, проектувальних, корекційно-педагогічних і комунікативних умінь. Основними професійними вміннями, на думку цих вчених, є: створювати розвивальне освітнє середовище, надавати соціально-педагогічну підтримку дитині з особливими освітніми потребами; реалізовувати принцип командного підходу за взаємодії 3 різними фахівцями; застосовувати методи формування позитивного соціально-психологічного клімату у класному колективі; ситуативно швидко реагувати на проблеми, що можуть виникати в дитини й оперативно вирішувати їх; володіти методичними прийомами адаптації навчальної програми до особливих потреб дитини; здійснювати паритетні контакти із сім'єю дитини 3 особливими потребами тощо;

- особистісна складова містить систему професійних якостей, системоутворювальними з яких є емпатійність, рефлективність, когнітивна відкритість, гнучкість, самоорганізованість тощо. Саме здатність гнучко реагувати на особливі освітні потреби дітей з особливостями психофізичного розвитку, а також знаходити альтернативні форми комунікації 3 такою дитиною вважається однією 3 головних професійних якостей учителя в умовах інклюзивного навчання [9, с. 114-115].

Згідно $з$ п. 31 ст. 48 Закону України “Про загальну середню освіту" Кабінету Міністрів України, Раді Міністрів Автономної Республіки Крим, обласним державним адміністраціям, Київській та Севастопольській міським державним адміністраціям і органам місцевого самоврядування доручено до 1 вересня 2018 р. забезпечити:

- зміну типу підпорядкованих шкіл-інтернатів (крім закладів середньої освіти для дітей з порушенням інтелектуального розвитку) на гімназію, ліцей відповідно до вимог цього Закону зі збереженням у складі цих закладів освіти інтернатів з частковим або повним утриманням учнів (вихованців) за рахунок засновника (засновників). Припинення функціонування інтернатів у складі таких закладів можливе лише після вирішення в установленому порядку питання здобуття учнями (вихованцями) освіти та/або отримання відповідних соціальних послуг за місцем їхнього проживання (реєстрації) чи місцем проживання (реєстрації) іхніх батьків;

- створення обласних (міських у містах Києві та Севастополі) ресурсних центрів підтримки інклюзивної освіти, а також районних, міських (районних у містах) інклюзивно-ресурсних центрів, у тому числі в об'єднаних територіальних громадах, шляхом реорганізації існуючої мережі психолого-медико-педагогічних консультацій [10].

Ще однією актуальною проблемою є ставлення до інклюзї батьків 
дітей з особливими освітніми потребами, які не завжди готові віддати свою дитину навчатися у звичайну школу поряд із дітьми з типовим рівнем розвитку, намагаючись захистити свою дитину від навколишнього світу, побоюючись неприйняття, образ, глузування з боку інших, тому для них найприйнятнішим є спеціальний заклад або індивідуальна форма навчання. Такі батьки дітей з особливими потребами мають ряд усталених упереджень щодо освіти в загальноосвітніх школах, навіть інклюзивних. Одне з основних - негативне ставлення до дітей з особливими потребами з боку вчителів ЗОШ, батьків здорових дітей та самих дітей.

Як зазначає Д. Величко, “на загал панівною є думка, що соціум не готовий до адекватного сприйняття дітей з особливими потребами. Що значнішою є проблема дитини, то більше вона та їі батьки стикаються 3 негативним ставленням з боку як дорослих, так і дітей. Саме тому батьки намагаються вберегти своїх дітей від психологічних травм і не хочуть, аби вони виконували роль “тренажерів” для формування суспільної толерантності" [11, с. 48]. Вирішального значення для розв'язання цієї проблеми набуває просвітницька робота школи, батьківських комітетів, батьків дітей з особливими освітніми потребами, громадських організацій, держави загалом.

Висновки. Особливості підготовки вчителів в умовах запровадження ефективної системи інклюзивної освіти в Україні можлива на основі взаємодії різних факторів, насамперед державної підтримки, удоско- налення іii нормативно-правового забезпечення, поліпшення методичного та кадрового забезпечення інклюзивної освіти, перехід післядипломної педагогічної освіти від дидактично-методичної спрямованості, забезпечення компенсаторної функції до підвищення професійної компетентності та професійного й особистісного розвитку фахівців [9, c. 122].

Грунтуючись на принципі непереривності освіти, вагомими чинниками успішного впровадження інклюзивного навчання є:

- скорочення чисельності дітей у класах, де є діти з особливими освітніми потребами;

- включення курсу з практики впровадження інклюзивної освіти в Україні до програм вищої педагогічної освіти та підвищення кваліфікації вчителів;

- внесення змін до законів України "Про дошкільну освіту", “Про загальну середню освіту”, "Про позашкільну освіту";

- культивування в суспільстві позитивної думки стосовно інклюзивної освіти шляхом залучення до цієї справи засобів масової інформаціï;

- розвиток системи підготовки кадрів для роботи 3 дітьми з особливими освітніми потребами;

- проведення психологічних тренінгів для батьків та педагогічних працівників для зменшення рівня побоювань та неприйняття змін в освітніх закладах, які будуть пов'язані з впровадженням інклюзії;

- застосування новітніх технологій навчання для дітей з особливими освітніми потребами. 


\section{СПИСОК ВИКОРИСТАНИХ ДЖЕРЕЛ}

1. Конвенція ООН про права дитини [Електронний ресурс]. - Режим доступу: http://zakon.rada.gov.ua/ laws/show/995_021

2. Закон України "Про освіту" [Електронний ресурс]. - Режим доступу: httр://zakon.rada.gov.ua/laws/ show/2145-19

3. Постанова Кабінету Міністрів України від 14 лютого 2017 р. № 88 “Про затвердження Порядку та умов надання субвенції з державного бюджету місцевим бюджетам на надання державної підтримки особам 3 особливими освітніми потребами" [Електронний ресурс]. - Режим доступу: http://zakon.rada.gov.ua/ laws/show/88-2017-\%D0\%BF

4. Наказ МОН України від 01.02.2018 р. № 90 "Про внесення змін до наказу Міністерства освіти і науки України від 6 грудня 2010 р. № 1205” [Електронний ресурс]. - Режим доступу: http:// search.ligazakon.ua/1_doc2.nsf/link1/ RE31678.html

5. Розвиток професійної компетентності психолога у системі післядипломної освіти: науково-методичний супровід: монографія [О. І. Гура, Т. С. Гура, В. Я. Ястребова та ін.]; за ред. Т. С. Гури. - Запоріжжя: Просвіта, 2011. - 138 с.

6. Сухомлинський В. О. Сто порад учителеві. - К.: Рад. шк., 1988. $304 \mathrm{c}$.

7. Швень Я. Воршопи. Управлінська діяльність. - К.: Вид. група "Шкільний світ", 2018. - 112 с.

8. Постанова Кабінету Міністрів України від 12 липня 2017 р. № 545 "Про затвердження Положення про інклюзивно-ресурсний центр” [Електронний ресурс]. - Режим доступу: http://zakon.rada.gov.ua/ laws/show/545-2017-\%D0\%BF
9. Розвиток інклюзивного освітнього середовища в Запорізькій області: науково-методичний аспект: монографія / [упоряд.: Т. С. Гура; ред. Т. Я. Озерова]. - Запоріжжя: СТАТУС, 2018. - 358 c.

10. Закон України "Про загальну середню освіту” [Електронний ресурс]. Режим доступу: http://zakon.rada. gov.ua/laws/show/651-14

11. Величко Д. В. Впровадження інклюзивної освіти в Україні // Вісн. Чернігів. нац. пед. ун-ту. Серія : Педагогічні науки. - 2015. - Вип. 125. - С. 46-49. - Режим доступу: http://nbuv.gov.ua/UJRN/ VchdpuP_2015_125_14

\section{REFERENCES}

1. Konventsiia OON pro prava dytyny [United Nations Convention on the Rights of the Child]. (n.d.). zakon. rada.gov.ua. Retrieved from http://zakon.rada.gov.ua/laws/show/995_021 [in Ukrainian].

2. Zakon Ukrainy "Pro osvitu" vid 05 veresnia 2017 roku № 2145-VIII [The Law of Ukraine "On Education" from September 5 2017, № 2145VIII]. zakon.rada.gov.ua. Retrieved from http://zakon.rada.gov.ua/laws/ show/2145-19 [in Ukrainian].

3. Postanova Kabinetu Ministriv Ukrainy "Pro zatverdzhennia Poriad$\mathrm{ku}$ ta umov nadannia subventsii $\mathrm{Z}$ derzhavnoho biudzhetu mistsevym biudzhetam na nadannia derzhavnoi pidtrymky osobam z osoblyvymy osvitnimy potrebamy" vid 14 liutoho 2017 roku № 88 [Resolution of the Cabinet of Ministers of Ukraine "On Approval of the Procedure and Conditions for Granting Subvention from the State Budget to Local Budgets for State Support to Persons with Special Educational Needs" dated February 14 2017, № 88]. zakon.rada.gov.ua. Retrieved from http://zakon.rada.gov. 
ua/laws/show/88-2017-\%D0\%BF [in Ukrainian].

4. Nakaz MON Ukrainy "Pro vnesennia zmin do nakazu Ministerstva osvity i nauky Ukrainy vid 06 hrudnia 2010 roku № 1205" vid 01 liutoho 2018, № 90 [Order of the Ministry of Education and Science of Ukraine "On Amendments to the Order of the Ministry of Education and Science of Ukraine of December 06, 2010 № 1205” from February 1 2018, № 90]. search.ligazakon.ua. Retrieved from http://search.ligazakon.ua/1_doc2. nsf/link1/RE31678.html [in Ukrainian].

5. Hura O. I., Hura, T. Ye., Yastrebova V. Ya. (2011). Rozvytok profesiinoi kompetentnosti psykholoha u systemi pisliadyplomnoi osvity: naukovo-metodychnyi suprovid [Development of psychologist professional competence in the postgraduate education system]. T. Ye. Hura (Ed.). Zaporizhzhia: Prosvita [in Ukrainian].

6. Sukhomlynskyi V. O. (1988). Sto porad uchytelevi [One Hundred Advice to the Teacher]. Kyiv: Rad. shk. [in Ukrainian].

7. Shven Ya. (2018). Vorshopy. Upravlinska diialnist [Workshops. Management activity]. Kyiv: "Vyd. hrupa "Shkilnyi svit" [in Ukrainian].

8. Postanova Kabinetu Ministriv Ukrainy "Pro zatverdzhennia Polozhennia pro inkliuzyvno-resursnyi tsentr" vid 12 lypnia 2017 roku, № 545 [Resolution of the Cabinet of Ministers of Ukraine "On Approval of the Regulations on the Inclusive-Resource Center" dated July 12 2017, № 545]. zakon.rada. gov.ua. Retrieved from http://zakon. rada.gov.ua/laws/show/545-2017$\% \mathrm{D} 0 \% \mathrm{BF}$ [in Ukrainian].

9. Hura T. Ye. (2018). Rozvytok inkliuzyvnoho osvitnoho seredovyshcha v Zaporizkii oblasti: naukovo-metodychnyi aspect [Development of inclusive educational environment in Zaporizhzhya region: scientific and methodical aspect]. T. Ya. Ozerova (Ed.). Zaporizhzhia: STATUS [in Ukrainian].

10. Zakon Ukrainy "Pro zahalnu seredniu osvitu” vid 13 travnia 1999, № 651XIV [The Law of Ukraine "On General Secondary Education" from May 13 1999, № 651-XIV]. zakon.rada.gov. ua. Retrieved from http://zakon.rada. gov.ua/laws/show/651-14 [in Ukrainian].

11. Velychko D. V. (2015). Vprovadzhennia inkliuzyvnoi osvity $\mathrm{v}$ Ukraini [Introduction of inclusive education in Ukraine]. Visnyk Chernihivskoho natsionalnoho pedahohichnoho universytetu. Seriia: Pedahohichni nauky - Bulletin of Chernihiv National Pedagogical University. Series: Pedagogical Sciences, 125, 46-49. Retrieved from http://nbuv.gov.ua/UJRN/VchdpuP_2015_125_14[in Ukrainian]. 